7. Лавров Д. Заметки об Осетии и осетинах // Сборник материалов для описания местностей и племен Кавказа. Вып. 3. Тифлис, - 1883. С.1-

8. Сатцаев Э.Б. Конь в легендах и мифах иранских народов // Гуманитарные исследования. 2014. № 4 (52). - C. 77-82.

9. Сатцаев Э.Б. Культ коня у иранских народов // Всероссийские Миллеровские чтения. 2016. № 5. - С. 277-280.

10. Сокаева Д.В.Чудесный конь в преданиях, легендах циклов «ХатагБараг», «Красавица Салхая», «Красавица Балсуя» // Филологические науки. Вопросы теории и практики. 2014. № 4-3 (34). С. 175177.

11. Сокаева Д.В., Дзапарова Е.Б.Сюжетная мотивация мотива угона табуна лошадей в осетинском фольклоре: нартовский эпос, предание с элементами богатырской сказки // Материалы III Международной научной конференции, посвященной 75-летию Калмыцкого института гуманитарных исследований РАН. 2016. - С. 230-233.

12. Сокаева Д.В., Чочиев Г.В. Кабардинское предание о «кабанском князе» и происхождении шолохской породы лошадей //Известия СОИГСИ. 2013. № 10 (49). С. 102-107.

13. Хадикова А.Х. Традиционный этикет Осетии: автореф. дис.... канд. ист. наук / СанктПетербургский государственный университет СПб., 1992. - 16 с.

14. Цаллагова И.Н.Лингвистические особенности осетинской загадки // Диссертация на соискание ученой степени кандидата филологических наук / Северо-Осетинский государственный университет им. К.Л. Хетагурова. Владикавказ, 2010.

15. Клапрот Ю. Путешествие по Кавказу и Грузии, предпринятое в 1807-1808гг. // Осетины глазами русских и иностранных путешественников. Северо-Осетинское книжное издательство, 1967. C. $105-180$

16. Яновский А.Г. Осетия. Цхинвал, 1993. -26с.

17. Пфаф В. Путешествие по ущельям Северной Осетии // Сборник сведений о Кавказе (ССК). Тифлис, 1871.T.I. -C.127-176

\title{
Подшивалова К.А. \\ Роль леворадикальных организаций в формировании студенческого движения конца 1960-х гг. во Франции
}

Томский государственный педагогический университет (Россия, Томск)

doi:10.18411/spc-22-11-2017-32

idsp: 000001:spc-22-11-2017-32

\section{Аннотация}

В статье проводится анализ влияния левых организаций на студенческие бунты 1960-х гг. во Франции. Характеризуется роль леворадикальных организаций в усилении протестной активности в среде французского студенчества. Исследуются внешние, а также внутренние причины, оказавшие влияние на рост числа сторонников левых взглядов среди студентов.

Ключевые слова: Франция, 1968 год, студенты, система высшего образования, левые радикалы, студенческие организации, «Красный май», гошизм.

Студенческие волнения играли важную роль в протестных движениях самого широкого спектра: от небольших манифестаций за равноправие полов до весомых попыток свержения действующей власти. Процесс усиления роли студенческих объединений в контексте протестных движений 1960-х гг. стал одной из значимых тем для изучения в социологических и гуманитарных науках. Интерес к данной теме был обусловлен активизацией студенческих движений в конце 1960-х гг. Именно тогда студентам Западной и Восточной Европы, США, а также стран Азии и Латинской Америки удалось взбудоражить общественность. Рассматривая причины и истоки молодежных бунтов конца 1960-х гг., следует обратить внимание на состав, 
существующих на тот момент времени, студенческих организаций. Особую роль в них занимали представители радикалов - левые активисты.

Одним из наиболее ярких проявлений студенческой активности в конце 1960-х гг. стал феномен так называемого «Красного мая» во Франции. Наряду с остро нарастающим социально-политическим кризисом, к маю 1968 г. во Франции возникла еще одна не менее серьезная проблема: кризис высшей школы. Волнения среди студентов имели несколько причин, которые носили как внешний, так и внутренний характер. Прежде всего, они были обусловлены устаревшими консервативными порядками в системе образования Франции, сохранившимися еще с наполеоновских времен. Студентам высшей школы запрещалось участвовать в решении университетских дел, политическая деятельность в стенах университета также воспрещалась. Особую волну недовольства вызвал запрет на общение между парнями и девушками вовне учебного времени: студентам нельзя было посещать общежития противоположного пола. Наряду с этим, в конце $60-\mathrm{x}$ гг. XX в. на системе высшей школы Франции впервые стали сказываться последствия послевоенного демографического бума, приток молодежи из Алжира лишь усугубил эту ситуацию. Вузы оказались попросту переполнены. Так в 1962 г. во Франции было 292 тыс. студентов, что в 2 раза больше, чем в 1950-ом г. и в 10 раз больше, чем в 1900 г. [1, C.394]. Это спровоцировало избыток «интеллектуалов» в обществе, которые не получали гарантий трудоустройства даже при наличии диплома о высшем образовании. Также произошло и ухудшение качества высшего образования: оно сводилось к обеспечению будущего рабочего достаточно узкой совокупностью навыков и умений. Все это способствовало обострению социальной напряженности, что, в свою очередь, привело к возникновению радикально-настроенных группировок среди французских студентов. Таким образом, глобальные проблемы в системе высшего образования превратили студентов в один из самых незащищенных и радикально-настроенных слоев общества. Своим главным врагом они называли современную капиталистическую систему, превращающую человека в «одномерного» потребителя материальных благ, в безмолвного зрителя мимо текущей жизни, и именно ее винили в общественных проблемах [2, С. 74].

Французская молодежь 60-х гг. ХX в. отвергала установленные старшим поколением запреты и ограничения, критиковала ценности ее отцов: «общество», «семью», «родину», а также пропагандировала свободу сексуальных отношений. Молодые люди отказывались носить пиджаки и галстуки, так как желали даже внешне отличаться от старшего поколения, а сами галстук и пиджак считали атрибутами реакционности. В моду вошли свитера, потертые рваные джинсы, куртки, мини-юбки и т.д. Представители молодежи отпускали длинные волосы и отращивали бороды. Рокмузыка, зародившаяся в США и Великобритании, стала одним из составных элементов культуры французских студентов 60-х гг. ХХ в. Концерты таких французских рокзвезд как Джонни Холлидей и Сильвия Вартан воспринимались как вызов существующим порядкам, т.к. принимали весьма экспрессивную форму: рокмузыканты прибегали к усилителям звука, при этом соединяя музыку, пение, танец и даже акробатические номера воедино. Подобные концерты собирали огромные толпы молодежи и нередко заканчивались потасовками. Рок-музыка стала символом нового поколения, стремившегося к свободной жизни. Студенты пропагандировали разрыв со «старым миром», их протест был динамичным и ярким, выдвигал требование социальной свободы [3, С.97]. Очагом студенческих волнений «Красного мая» являлся факультет социологии и филологии в пригороде Парижа - Нантере. В Нантере существовали давние анархистские традиции. Еще в сентябре 1964 г. участники 
Анархистской федерации, «Черного и Красного» и Союза анархо-коммунистических групп провели совместное собрание в помещении Национальной Конфедерации Труда, где договорились о создании единой структуры Анархистская Студенческая Связь. А в конце февраля - начале марта в университете образовалась новая группа «бешенные». «Бешенными» называли самую радикально настроенную группу санкюлотов времен Великой французской революции. Нантеровские «бешенные» являлись нечто средним между политической организацией и молодежной субкультурой. Они одевались во все кожаное, ходили в черных очках, сохраняли трехдневную щетину. Одно из наиболее ярких студенческих движений 1968 г. также возглавляли представители леворадикальных группировок. «Движение 22 марта» представляло собой объединение студентов-гошистов. Гошизм (фp. gauchisme) - это обобщенное название французского леворадикального движения 1960-х - начала 1970-х гг. В состав вошли члены Объединенной Социалистической Партии, троцкисты из JCR, маоисты присоединились в конце апреля. Лишь одна группа отказалась принять участие в «Движении». Это были троцкисты из группы CLER [4, C.98]. Официального руководства у движения 22 марта не было, не было и вождей, однако были лидеры. Самым известным студенческим лидером 1968 г. был студент факультета филологии и социологии Даниэль Кон-Бендит. Сам Даниэль называл себя «рупором» движения. 22 марта 1968 г. под его предводительством произошло столкновение между полицией и студентами Нантеровского университета. Протест был направлен против действий властей, в связи с арестами студентов, выступающих против войны во Вьетнаме. Само «Движение 22 марта» опиралось на идеологию Ситуционисткого Интернационала под предводительством Ги Дебора. На тот момент «Ситуационисты» являлись популярной студенческой группой сформировавшиеся на филологическом факультете в Страсбурге. Они развернули в университетской среде масштабную дискуссию, опубликовав памфлет, который вскоре стал весьма популярен «О нищете студенческой жизни» («De la misère en milieu étudiant»). Памфлет представлял собой сборник выводов теории группы «Аргументы» на студенческую жизнь. Ситуционисты считали, что Запад достиг своего товарного изобилия и пришло время для «революции повседневной жизни». Эта революция предполагала отказ от подчинения государству, а также работы на него, отказ от выплаты налогов и полное отрицание устоявшихся общественных моральных норм.

Период с января по май 1968 г. для Франции ознаменовался быстрым идейноорганизационным развитием студенчества. Именно в это время их политическая и социальная активность стремительно возросла. После инцидента в Нантере, а также выступлений «Движения 22 марта», объединения студентов стали не просто собранием людей по интересам, а обрели форму настоящих организаций с собственными идеологией, мировоззрением и символикой. Группы левых радикалов, конфликтующие по вопросам теории между собой, объединились в акции «прямого действия», что повлекло за собой дальнейшие события, носящие название «Красного мая».

Таким образом, значимость роли леворадикальных организаций в событиях 1968 г. во Франции весьма очевидна. Гошисты распространяли революционно звучащие лозунги, пропагандирующие термины «оспаривания» и «отрицания». Под влиянием левых активистов, студенты отказывались сдавать экзамены, срывали занятия в знак протеста против привилегированного положения профессоров высшей школы, провозглашали «нет - буржуазному университету» и «нет - буржуазному обществу». Они организовывали митинги, хоть данные действия и противоречили университетскому уставу, запрещавшему политические собрания на территории университета. Например, 3 мая 1968 г. студенты Сорбонны вышли во двор 
университета на митинг против исключения из университета нескольких лидеров гошистов. Стоит отметить, что в руководстве студенческого профсоюза Национального союза студентов, также преобладали гошисты. Находясь под действием их пропаганды, студенты разбирали мостовые, переворачивали автомобили, рубили деревья и фонарные столбы, возводили баррикады в Латинском квартале. Леворадикальные организации были непосредственными участниками событий «Красного мая» во Франции. Они выступали активными агитаторами среди студенческой молодежи. Стали «рупором» студенческих волнений 1968 г.

$$
* * *
$$

1. Манфред А.З. История Франции. Т.3. М.: Наука, 1973. С. 394

2. Головко С.А. Высшая школа Франции. Актуальные проблемы и противоречия. Минск, 1980. С.74

3. Ушкова Е. Л. Ле Гофф Ж.-П. Новый «Разрыв поколений»: От мая 1968 года к движению против «Контракта первого найма».2007. № 4. С.97

4. Семенов А.Л. Борьба французских студентов за самоуправление в университете и обществе в 60 -е годы XX в. Опыт европейского федерализма. М., 2002. С. 98 